\title{
DEVELOPMENT OF A HEAT TREATMENT FOR INCREASING THE MECHANICAL PROPERTIES AND STRESS CORROSION RESISTANCE OF 7000 Al ALLOYS
}

\author{
RAZVOJ TOPLOTNE OBDELAVE ZA IZBOLJŠANJE MEHANSKIH \\ LASTNOSTI IN NAPETOSTNO KOROZIJSKO ODPORNOST 7000 \\ Al ZLITIN
}

\author{
Mehdi Shakouri', Mohammad Esmailian', Saeed Shabestari² \\ ${ }^{1}$ Advanced Material and Renewable Energy Department, Iranian Research Organization for Science and Technology (IROST), \\ P. O. Box 3353-5111, Tehran, Iran \\ ${ }^{2}$ Center of Excellence for High Strength Alloys Technology (CEHSAT), School of Metallurgy and Materials Engineering, \\ Iran University of Science and Technology (IUST), Narmak, 16846, Tehran, Iran \\ mshakoory@yahoo.com
}

Prejem rokopisa - received: 2016-10-10; sprejem za objavo - accepted for publication: 2017-04-19

doi:10.17222/mit.2016.297

\begin{abstract}
A retrogression and re-ageing (RRA) treatment is a three-step heat treatment that can improve both the mechanical strength and the corrosion resistance in aluminum alloys. In this work, the mechanical and stress corrosion properties under various ageing treatment conditions were investigated in an $\mathrm{Al}-8.5 \mathrm{Zn}-2.1 \mathrm{Mg}-2 \mathrm{Cu}-0.2 \mathrm{Ag}(\mathrm{w} / \%)$ alloy. The treatments were the T6 conventional method followed by a retrogression and re-ageing (RRA) treatment. Tensile test, scanning electron microscopy (SEM), energy-dispersive X-ray spectroscopy (EDS) and differential scanning calorimetry (DSC) were used to investigate the mechanical and stress corrosion cracking (SCC) properties. The results showed that both, the strength and the corrosion resistance criteria (SCR), which is defined as the ratio between the remaining strength percent in stressed and un-stressed conditions, improve after the RRA treatment. The tensile strength and SCR criteria for the T6 heat treatment were $547 \mathrm{MPa}$ and $71 \%$ initially and then increased to $612 \mathrm{MPa}$ and $95 \%$ for the RRA treatment, respectively. Moreover, the EDS results showed that in grain-boundary precipitates the Cu concentration is much higher for the RRA in comparison with the T6 treatment, but it is lower for the matrix precipitates in the RRA treatment.
\end{abstract}

Keywords: aluminium alloys, stress corrosion resistance, precipitation, retrogression and re-ageing

Obdelava $\mathrm{z}$ retrogresijo in ponovno oživitvijo (angl. RRA) je tristopenjska toplotna obdelava, s katero lahko izboljšamo tako mehansko trdnost kot odpornosti proti koroziji pri aluminijevih zlitinah. V pričujočem delu so bile raziskovane mehanske lastnosti in lastnosti odpornosti proti koroziji pri zlitini $\mathrm{Al}-8.5 \mathrm{Zn}-2.1 \mathrm{Mg}-2 \mathrm{Cu}-0.2 \mathrm{Ag}(w / \%)$ pod različnimi pogoji obdelave staranja. Izvedeni so bili testi po konvencionalni T6 metodi, z upoštevanjem RRA obdelave. Natezni preiskus, vrstična elektronska mikroskopija (SEM), energijsko disperzijska rentgenska spektroskopija (EDS) in DSC-testiranja so bili izvedeni, da bi raziskali mehanske in napetostno-korozijske lomne lastnosti (angl. SCC). Rezultati so pokazali, da se oba kriterija tako trdnost kot odpornost proti koroziji, ki definirata razmerje med procentom zaostale trdnosti pri napetostnih in nenapetostnih pogojih, po RRA-obdelavi izboljšata.

Ključne besede: aluminijeve zlitine, odpornost proti koroziji, oborine, retrogresija in ponovno staranje

\section{INTRODUCTION}

The $\mathrm{Al}-\mathrm{Zn}-\mathrm{Mg}-\mathrm{Cu}$ series aluminum alloys are precipitation-hardening alloys that are used extensively for light-weight structural applications, in particular in the aircraft industry. They have a combination of good strength and good stress corrosion resistance. ${ }^{1}$

The most popular heat treatment to gain the peakaged strength (T6X temper) is a solution treatment, quenching, stretching (for stress relief purposes) followed by artificial aging at $120{ }^{\circ} \mathrm{C}$ for $24 \mathrm{~h}$, but this temper is highly susceptible to SCC. In order to reduce this susceptibility, an over-aging treatment (T7X temper) is needed. ${ }^{2}$ This requirement becomes increasingly demanding as the solute contents are increased in commercial alloys in order to improve the mechanical properties even further.
To improve both the mechanical strength and corrosion resistance, it has been proposed to utilize an RRA treatment. This three-step heat treatment has been shown to offer a stress corrosion resistance as good as that of a T7X heat treatment, while keeping a strength comparable to that of a T6X temper. ${ }^{3,4}$ This type of heat treatment comprises three steps. First, an ageing step that leads to a T6 state. A second step (called retrogression or reversion) of short duration at high temperature dissolves part of the initially formed precipitates. Third heat treatment step at lower temperature leads to the desired microstructure. ${ }^{5}$

Stress corrosion cracking occurs under loading in a corrosive environment. Several investigations have reported that the SCC mechanism involves anodic dissolution, hydrogen-induced cracking, passive film rupture, hydrogen embrittlement, magnesium segregation to the 
grain boundaries and a precipitate-free zone (PFZ) along the grain boundary. ${ }^{6-10}$ However, the microstructural characteristics of $\mathrm{Al}-\mathrm{Zn}-\mathrm{Mg}-\mathrm{Cu}$ high strength aluminum alloys are well known to have a strong influence not only on the mechanical properties but also on the SCC susceptibility. Larger grain-boundary precipitates can trap more atomic hydrogen to nucleate hydrogen bubbles, thereby decreasing the hydrogen concentration at grain boundaries below a critical value is considered to prevent intergranular SCC fracture. ${ }^{11}$ Furthermore, the cathodic grain-boundary precipitates grow by depleting solute atoms. Studies showed that this leads to the broadening of the anodic PFZ, which contained no strengthen precipitation phase and as a result was soft and weak. ${ }^{12}$ The combination of tensile stress and anodic dissolution caused SCC.

SCC resistance is of practical importance for the industrial applications of the $\mathrm{Al}-\mathrm{Zn}-\mathrm{Mg}-\mathrm{Cu}$ series aluminum alloys. Various heat treatments in these alloys offer very different SCC properties. The SCR criteria are proposed to compare the SCC resistance.

The aim of this paper is to investigate the mechanical strength and SCC of a 7000 series aluminum alloy after conventional T6 and RRA treatments. The SCR criteria have been defined to easily compare the SCC resistance of this alloy after various treatments. SEM investigations were used to determine the effect of the heat treatments on the alloy's microstructure with the aim of studying its effect on SCC susceptibility. For comparison, the stress corrosion resistance of the alloy with different heat treatments was studied by the breaking load method according to ASTM G139 standard. ${ }^{13}$

\section{EXPERIMENTAL PART}

The samples used in this study were received as 8-mm-thick sheets that were homogenized, hot rolled and heat treated after being alloyed and casted. The chemical composition of the alloy is shown in Table $\mathbf{1}$.

Table 1: Chemical composition (in mass fractions, w/\%) of fabricated alloy

\begin{tabular}{|c|c|c|c|c|c|c|c|}
\hline $\begin{array}{c}\text { Alloy } \\
\text { No. }\end{array}$ & $\mathrm{Zn}$ & $\mathrm{Cu}$ & $\mathrm{Mg}$ & $\mathrm{Fe}$ & $\mathrm{Si}$ & $\mathrm{Zr}$ & $\mathrm{Ag}$ \\
\hline 1 & 8.5 & 2 & 2.1 & 0.18 & 0.16 & 0.20 & 0.19 \\
\hline
\end{tabular}

An induction melting furnace used for melting and the melt was poured in a water-cooled copper mold. The as-cast specimens were homogenized at $460{ }^{\circ} \mathrm{C}$ for $24 \mathrm{~h}$ and hot rolled to about $33 \%$ reduction. Hot rolling was

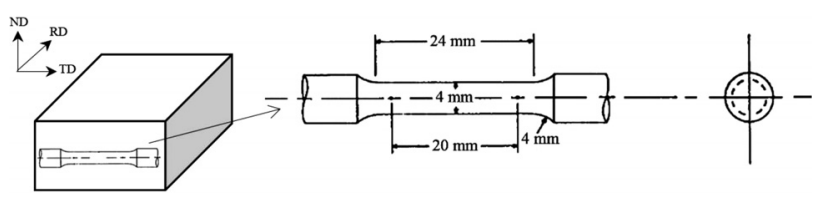

Figure 1: Schematic showing the preparation of tensile samples from the specimens performed with $40 \mathrm{~min}^{-1}$ rolling speed at $430{ }^{\circ} \mathrm{C}$. The specimens were milled to tensile samples according to the ASTM E8M standard. A schematic showing the preparation of tensile samples from the specimens is given in Figure 1.

A solution heat treatment was done at $471^{\circ} \mathrm{C}$ for $6 \mathrm{~h}$ followed by a water quenching. T6 ageing was performed for $24 \mathrm{~h}$ at $120{ }^{\circ} \mathrm{C}$ (T6 temper). The scheme of the retrogression and re-ageing treatment is shown in Figure 2.

Mechanical properties measurements were made at ambient temperature on the specimens machined according to the ASTM E8M-04 small size standard. The average of three tests was used for each result. The test's strain rate was $10^{-3} / \mathrm{s}$.

The SEM analysis was performed on a TESCAN scanning electron microscope. Thermal analysis was performed in a DSC 1 Mettler Toledo differential scanning calorimeter. Polished alloy disks with a diameter of $5 \mathrm{~mm}$ and $0.6 \mathrm{~mm}$ thick were sealed in aluminum pans and heated in a flowing argon atmosphere at a constant heating rate of $10{ }^{\circ} \mathrm{C} / \mathrm{min}$. The flowing rate of the argon was $100 \mathrm{~mL} / \mathrm{min}$.

The stress corrosion tests were performed according to the ASTM G139 standard. The Neutral $3.5 \%$ Sodium Chloride Solution was prepared in accordance with the requirements of the ASTM G44 standard. The ASTM G49 standard was used for preparation of direct tension stress corrosion test specimens. A $207 \mathrm{MPa}$ stress for the cycle of $4 \mathrm{~d}$ was applied as per section 8-2 of the ASTM G139 standard. In order to eliminate the corrosion other than SCC (such as pitting), some specimens were tested unstressed. The ratio of remaining strength of stressed and unstressed samples represented in percent, were calculated as SCR criteria for different treatment.

\section{RESULTS AND DISCUSSION}

\subsection{Mechanical strength}

The mechanical strength of the alloy was $547 \mathrm{MPa}$ after the T6 treatment and was $612 \mathrm{MPa}$ after the RRA treatment. The RRA treatment leads to an about $12 \%$ increase in mechanical strength. While T6 treatment is carried out to ensure maximum strength; the RRA

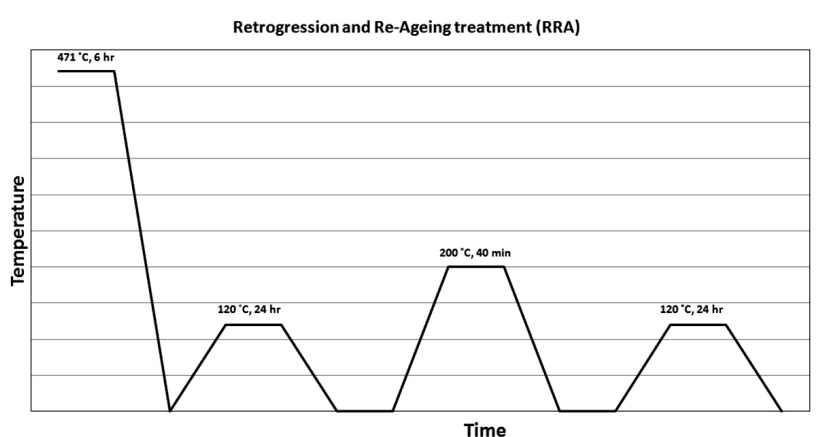

Figure 2: Scheme of the RRA treatment 
M. SHAKOURI et al.: DEVELOPMENT OF A HEAT TREATMENT FOR INCREASING THE MECHANICAL PROPERTIES ...

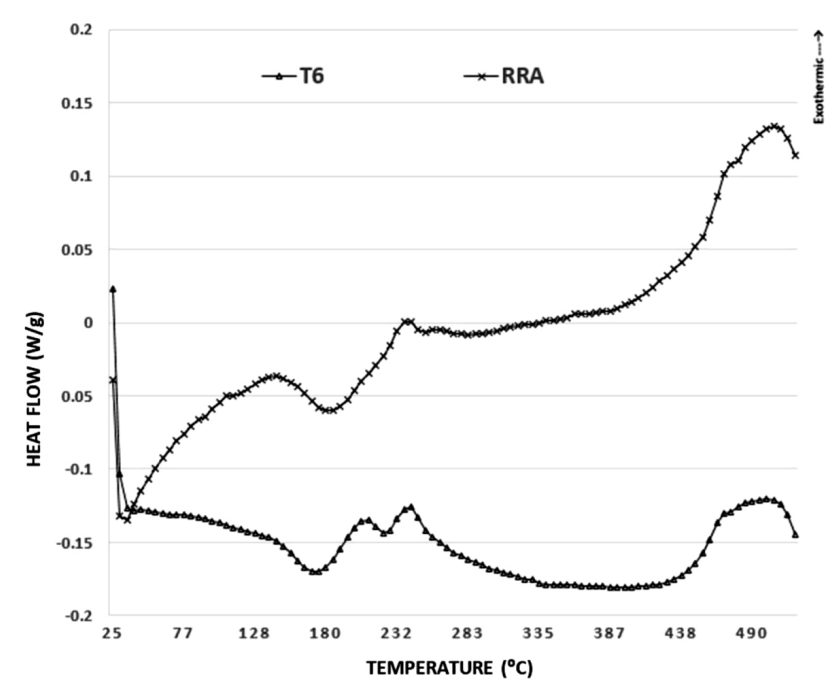

Figure 3: DSC curves for T6 and RRA treatment

treated samples show higher strength. It seems that the performed T6 treatment does not lead to precipitation of all the alloying elements and yet there are elements in the solution. To investigate this further, DSC analysis was conducted on the samples.

\subsection{DSC results}

Figure 3 shows the DSC analysis for the T6 and RRA treatment. Unlike the RRA treatment, the T6 curve shows two exothermic peaks at temperatures between $200{ }^{\circ} \mathrm{C}$ and $245^{\circ} \mathrm{C}$. The RRA curve in this region has only one small peak at about $240{ }^{\circ} \mathrm{C}$. These peaks are results of $\eta$ and $\eta^{\prime}$ precipitation from solid solution. ${ }^{14-16}$ In the RRA curve, there exists only one peak related to $\eta$ precipitation. This means that there are still a lot of elements in solid solution after T6 treatment suggesting that either time or temperature or both are not enough for diffusion and precipitation of the elements. As a result, the maximum strength has not achieved.

\subsection{Stress corrosion cracking}

Stress corrosion tests were performed according to the ASTM G139 standard for direct tension stress corrosion test method. Figure 4 shows the strength of T6 and RRA samples after exposure to corrosive $3.5 \%$ sodium chloride solution without stressing and with a $207 \mathrm{MPa}$ stress after $4 \mathrm{~d}$. As expected, strength is dropped in both the T6 and RRA treatment after the SCC test. After the $\mathrm{SCC}$ test with $207 \mathrm{MPa}$ constant stresses for $4 \mathrm{~d}$ in corrosive solution, the strength of RRA treated samples decreased from $612 \mathrm{MPa}$ to $545 \mathrm{MPa}$. Accordingly, the strength of the T6 treated samples dropped from 547 $\mathrm{MPa}$ to $367 \mathrm{MPa}$. Calculating the results in percentages, gives us a better understanding of the strength reduction.

The test was conducted in corrosive solution in two stress conditions: un-stressed and with constant $207 \mathrm{MPa}$ tension stress. The mechanical strength decreased for

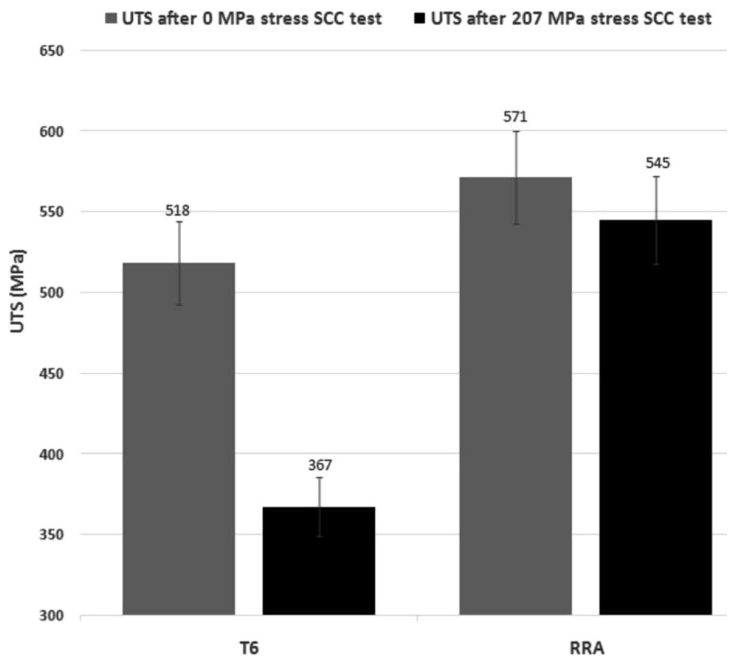

Figure 4: Direct tension stress corrosion cracking test after T6 and RRA treatment

both conditions. In order to better demonstrate the SCC results, it is most useful to calculate the remaining strength after SCC test and subtract the effect of corrosion methods other than SCC (such as pitting). To achieve this, the percentage of SCR ratio of remaining strength of stressed and unstressed samples is defined as stress corrosion resistance SCR. The SCR results of the alloy after the T6 and RRA heat treatments are shown in Figure 5. The remaining strengths of the unstressed samples after RRA and T6 treatments were $94.7 \%$ and $93.3 \%$, respectively, which are not much different. It means that unstressed corrosion results for both treatments were almost identical. However, the remaining strength percentages in the constant stress condition were very different. The remaining strength percentage was $89 \%$ for the RRA treatment and $68 \%$ for the T6 treatment. The SCR for the RRA treatment was $95 \%$ and for the T6 treatment it was $71 \%$. A significant im-

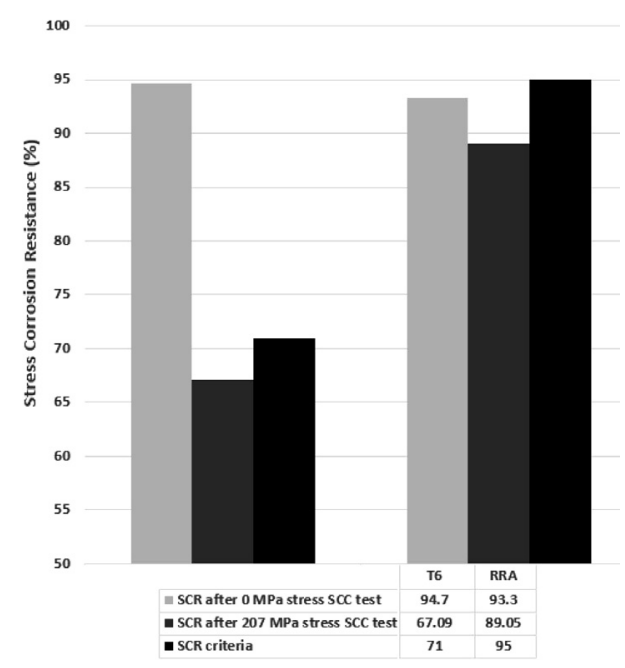

Figure 5: The SCR results of the alloy after T6 and RRA heat treatments 
M. SHAKOURI et al.: DEVELOPMENT OF A HEAT TREATMENT FOR INCREASING THE MECHANICAL PROPERTIES ...

provement in the stress corrosion cracking has been achieved after the RRA treatment.

\subsection{SEM and EDS analysis}

The SEM micrographs of the T6 and RRA samples are shown in Figures $\mathbf{6}$ and 7.

Comparison of these two micrographs shows that, after the RRA treatment the grain-boundary precipitates have lost their continuity and divided to relatively larger particles. This is an essential factor for reducing the intergranular corrosion and consequently reducing the stress corrosion cracking. Two basic mechanisms of the SCC in 7000 series aluminum alloys have been proposed: anodic dissolution and cathodic dissolution (hydrogen embrittlement). ${ }^{6}$ The precipitates in the grain boundaries have the electrode potential different from the Al matrix. This would result in the anodic dissolution and form defects in a chloride solution. The hydrogen atoms produced in the crack tip also lead to the hydrogen embrittlement in the grain boundaries. The large size and distance of the grain-boundary particles could decrease the anodic dissolution speed. These particles can also act as the trapping sites for atomic hydrogen and transform

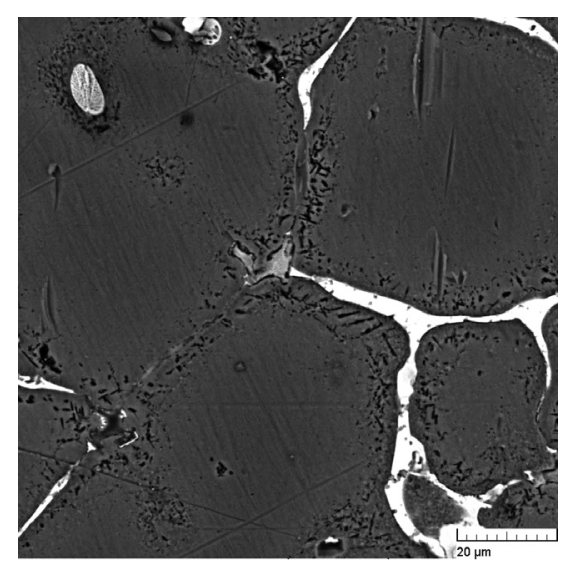

Figure 6: SEM micrograph of T6 sample showing continuous precipitates along the grain boundary

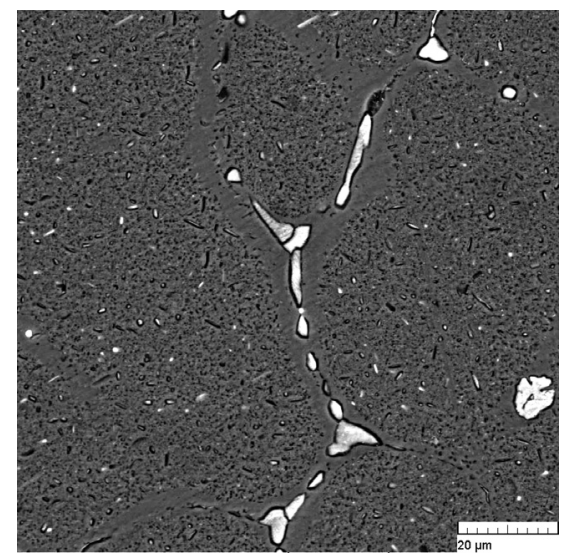

Figure 7: SEM micrograph of RRA sample showing less continuous precipitates along the grain boundary in comparison to the T6 sample
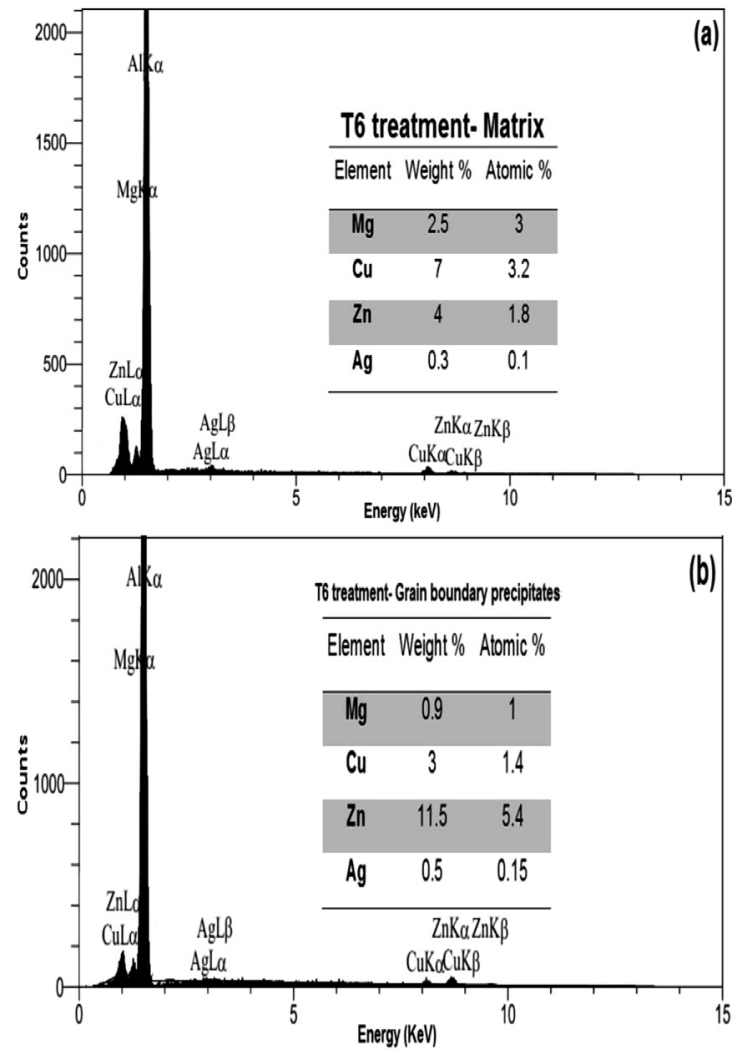

Figure 8: EDS analysis of T6 sample: a) matrix, b) grain boundary precipitates
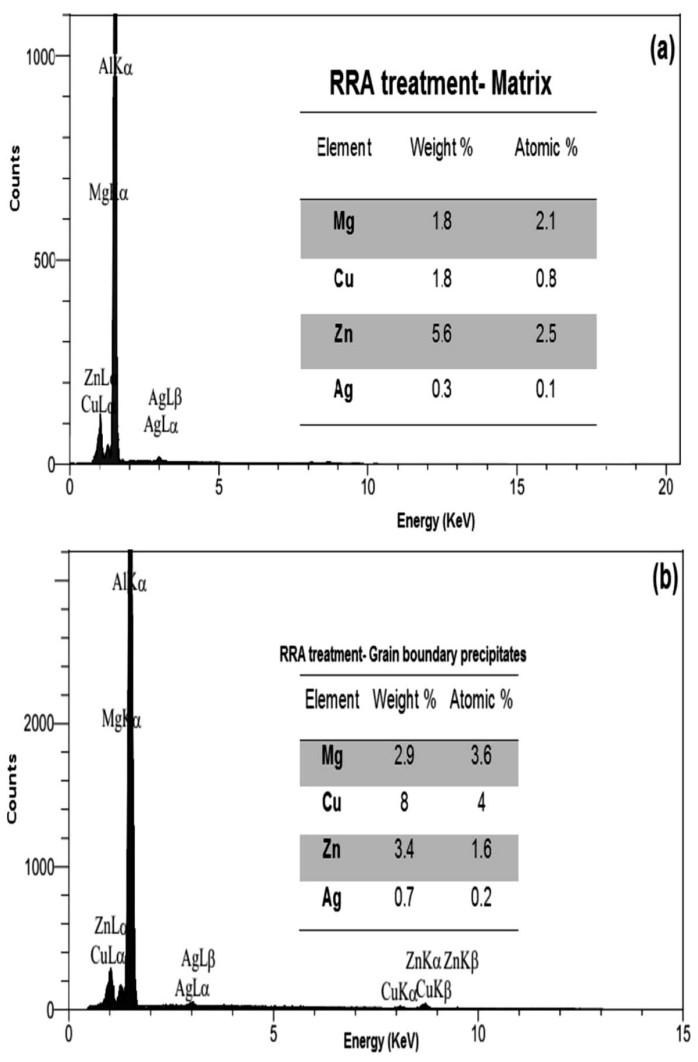

Figure 9: EDS analysis of RRA sample: a) matrix; b) grain boundary precipitates 
them to molecular hydrogen bubbles to reduce the concentration of the atomic hydrogen at the grain boundaries. Both the size and distance of the grain-boundary precipitates in RRA treated alloy were larger than that in T6 treated alloy, therefore, the SCR criteria after RRA treatment is higher than the T6 treatment.

Another factor showing SCC resistance improvement after RRA treatment is the concentration changes of precipitates and matrix. The $\mathrm{Zn}$ and $\mathrm{Cu}$ atoms have opposite effects on the electrochemical properties of alumi num. ${ }^{17,18}$ In a corrosive medium, the $\eta$ phase in grain boundary is very active and anodic with respect to the matrix. ${ }^{19} \mathrm{Cu}$ enrichment of precipitates after RRA increases the electrode potential of the grain boundaries and decreases the activity of grain-boundary phases. Figures 9 and $\mathbf{1 0}$ show the EDS analysis of the grainboundary precipitates and matrix after RRA and T6 treatment. Figure 8a shows the $\mathrm{Cu}$-rich matrix after the T6 treatment while according to Figure $\mathbf{8 b}$, the precipitates are Zn-reach. After RRA treatment, the matrix depleted from $\mathrm{Cu}$ atoms and the grain boundary precipitates were $\mathrm{Cu}$-enrichment (Figures 9a to 9b). Large variations in concentration of solute atoms happen during the RRA treatment. $\mathrm{Zn}$ atoms have a higher diffusivity than $\mathrm{Cu}$ atoms and leave the precipitates first after the reversion stage..$^{20}$ As a result, the $\mathrm{Zn}$ content of the matrix increases and a corresponding increase in the $\mathrm{Cu}$ precipitate content happens. This happens reversely in the T6 treatment, where $\mathrm{Zn}$ incorporates first the precipitates, resulting in a high $\mathrm{Zn}$ content of the precipitates and high $\mathrm{Cu}$ matrix content. The $\mathrm{Zn}$ and $\mathrm{Cu}$ atoms have opposite effects on the electrochemical properties of aluminum. ${ }^{21} \mathrm{~A}$ change in the corrosion behavior of the 7000 series aluminum alloy is related to changes in precipitate composition and particularly to a $\mathrm{Cu}$ enrichment of the precipitates. ${ }^{22}$ During the RRA treatment, the precipitates enrich by $\mathrm{Cu}$ atoms (Figure 9b) and this factor as well as other factors improves the SCC resistance.

\section{CONCLUSIONS}

The mechanical strength of an $\mathrm{Al}-8.5 \mathrm{Zn}-2.1 \mathrm{Mg}-$ $2 \mathrm{Cu}-0.2 \mathrm{Ag}(w / \%)$ alloy after conventional T6 treatment was lower than the mechanical strength after RRA treatment.

SCR is a useful criteria to compare the SCC in $\mathrm{Al}-\mathrm{Zn}-\mathrm{Mg}-\mathrm{Cu}$ alloys after various heat treatments. The SCR of the $\mathrm{Al}-8.5 \mathrm{Zn}-2.1 \mathrm{Mg}-2 \mathrm{Cu}-0.2 \mathrm{Ag}(w / \%)$ alloy after conventional T6 treatment was $71 \%$ and was $95 \%$ after RRA treatment. The SCC improved significantly after the RRA treatment.

The SCC improvement after the RRA treatment related to $\mathrm{Cu}$ enrichment of the precipitates along with the discontinuities of the grain-boundary precipitates.

\section{REFERENCES}

${ }^{1}$ T. Dursun, C. Soutis, Recent developments in advanced aircraft aluminium alloys, Materials \& Design, 56 (2014), 862-871, doi:10.1016/j.matdes.2013.12.002

${ }^{2}$ D. Liu, B. Xiong, F. Bian, Z. Li, X. Li, Y. Zhang, F. Wang, H. Liu, In situ studies of microstructure evolution and properties of an $\mathrm{Al}-7.5 \mathrm{Zn}-1.7 \mathrm{Mg}-1.4 \mathrm{Cu}-0.12 \mathrm{Zr}$ alloy during retrogression and reaging, Materials \& Design, 56 (2014), 1020-1024, doi:10.1016/ j.matdes.2013.12.006

${ }^{3}$ J. Li, N. Birbilis, C. Li, Z. Jia, B. Cai, Z. Zheng, Influence of retrogression temperature and time on the mechanical properties and exfoliation corrosion behavior of aluminium alloy AA7150, Materials Characterization, 60 (2009) 11, 1334-1341, doi:10.1016/ j.matchar.2009.06.007

${ }^{4}$ R. Bucci, C. Warren, E. Starke, The Need for New Materials in Aging Aircraft Structures, Journal of Aircraft, 37 (2000) 1, 122-129, doi:10.2514/2.2571

${ }^{5}$ D. Feng, X. M. Zhang, S. D. Liu, and Y. L. Deng, Non-isothermal retrogression and re-ageing treatment schedule for AA7055 thick plate, Materials \& Design, 60 (2014), 208-217, doi:10.1016/ j.matdes.2014.03.064

${ }^{6}$ D. Najjar, T. Magnin, T. J. Warner, Influence of critical surface defects and localized competition between anodic dissolution and hydrogen effects during stress corrosion cracking of a 7050 aluminium alloy, Materials Science and Engineering: A, 238 (1997) 2, 293-302, doi:10.1016/S0921-5093(97)00369-9

${ }^{7} \mathrm{~T}$. Burleigh, The postulated mechanisms for stress corrosion cracking of aluminum alloys: a review of the literature 1980-1989, Corrosion, 47 (1991) 2, 89-98, doi:10.5006/1.3585235

${ }^{8}$ R. Jones, D. Baer, M. Danielson, J. Vetrano, Role of Mg in the stress corrosion cracking of an Al-Mg alloy, Metallurgical and Materials Transactions A, 32 (2001) 7, 1699-1711, doi:10.1007/s11661001-0148-0

${ }^{9}$ E. Pugh, Progress toward understanding the stress corrosion problem, Corrosion, 41 (1985) 9, 517-526, doi:10.5006/1.3583022

${ }^{10}$ A. Sedriks, J. Green, D. Novak, Corrosion processes and solution chemistry within stress corrosion cracks in aluminum alloys, Proceedings of NACE, 1971, 569-575

${ }^{11}$ T. Tsai, T. Chuang, Role of grain size on the stress corrosion cracking of 7475 aluminum alloys, Materials Science and Engineering: A, 225 (1997) 1-2, 135-144, doi:10.1016/S0921-5093(96)10840-6

${ }^{12}$ T. Pardoen, D. Dumont, A. Deschamps, Y. Brechet, Grain boundary versus transgranular ductile failure, Journal of the Mechanics and Physics of Solids, 51 (2003) 4, 637-665, doi:10.1016/S00225096(02)00102-3

${ }^{13}$ ASTM 139:2005(G)- Standard test method for determining stresscorrosion cracking resistance of heat-treatable aluminum alloy products using breaking load method, ASTM International, West Conshohocken

${ }^{14}$ K. Ghosh, N. Gao, Determination of kinetic parameters from calorimetric study of solid state reactions in $7150 \mathrm{Al}-\mathrm{Zn}-\mathrm{Mg}$ alloy, Transactions of Nonferrous Metals Society of China, 21 (2011) 6, 1199-1209, doi:10.1016/S1003-6326(11)60843-1

${ }^{15}$ T. Marlaud, A. Deschamps, F. Bley, W. Lefebvre, B. Baroux, Influence of alloy composition and heat treatment on precipitate composition in Al-Zn-Mg-Cu alloys, Acta Materialia, 58 (2010) 1 , 248-260, doi:10.1016/j.actamat.2009.09.003

${ }^{16}$ J. G. Tang, H. Chen, X. M. Zhang, S. D. Liu, W. J. Liu, H. Ouyang, H. P. Li, Influence of quench-induced precipitation on aging behavior of Al-Zn-Mg-Cu alloy, Transactions of Nonferrous Metals Society of China, 22 (2012) 6, 1255-1263, doi:10.1016/S1003-6326(11) 61313-7

${ }^{17}$ R. W. Revie, H. H. Uhlig, Uhlig's corrosion handbook: vol. 51, John Wiley \& Sons, Hoboken 2011

${ }^{18}$ G. Silva, B. Rivolta, R. Gerosa, U. Derudi, Study of the SCC Behavior of 7075 Aluminum Alloy After One-Step Aging at $163^{\circ} \mathrm{C}$, Journal of Materials Engineering and Performance, 22 (2013) 1, 210-214, doi:10.1007/s11665-012-0221-4 


\section{MATERIALI IN TEHNOLOGIJE/MATERIALS AND TECHNOLOGY (1967-2017) - 50 LET/50 YEARS}

M. SHAKOURI et al.: DEVELOPMENT OF A HEAT TREATMENT FOR INCREASING THE MECHANICAL PROPERTIES ...

${ }^{19}$ S. Maitra, G. English, Mechanism of localized corrosion of 7075 alloy plate, Metallurgical and Materials Transactions A, 12 (1981) 3, 535-541, doi:10.1007/BF02648553

${ }^{20}$ H. Bakker, H. Bonzel, C. Bruff, M. Dayananda, W. Gust, J. Horvath, I. Kaur, G. Kidson, A. LeClaire, H. Mehrer, Diffusion in solid metals and alloys/Diffusion in festen metallen und legierungen: vol. 26, Springer, Berlin 1990

${ }^{21}$ E. Hollingsworth, H. Hunsicker, Corrosion of aluminum and aluminum alloys, ASM Handbook, 13 (1987), 583-609

${ }^{22}$ J. T. Staley, S. Byrne, E. Colvin, K. Kinnear, Corrosion and stresscorrosion of 7xxx-w products, Materials Science Forum, 217 (1996), 1587-1592, doi:10.4028/MSF.217-222.1587 